This is the author's final, peer-reviewed manuscript as accepted for publication. The publisher-formatted version may be available through the publisher's web site or your institution's library.

\title{
Big Brother or big bother? E-monitoring the salesforce
}

Susan K. DelVecchio, Dawn R. Deeter-Schmelz, Kenneth Anselmi

\section{How to cite this manuscript}

If you make reference to this version of the manuscript, use the following information:

DelVecchio, S. K., Deeter-Schmelz, D. R., \& Anselmi, K. (2013). Big Brother or big bother? E-monitoring the salesforce. Retrieved from http://krex.ksu.edu

\section{Published Version Information}

Citation: DelVecchio, S. K., Deeter-Schmelz, D. R., \& Anselmi, K. (2013). Big Brother or big bother? E-monitoring the salesforce. Journal of Business \& Industrial Marketing, 28(4), 288-302.

Copyright: @ Emerald Group Publishing Limited

Digital Object Identifier (DOI): doi:10.1108/08858621311313893

Publisher's Link: http://www.emeraldinsight.com/journals.htm?issn=0885$8624 \&$ volume $=28 \&$ issue $=4 \&$ articleid $=17087187 \&$ show $=\mathrm{html}$

This item was retrieved from the K-State Research Exchange (K-REx), the institutional repository of Kansas State University. K-REx is available at http://krex.ksu.edu 
Big Brother or Big Bother? E-Monitoring the Salesforce

August 6, 2011 


\title{
Big Brother or Big Bother? E-Monitoring the Salesforce
}

\begin{abstract}
Advances in communication and information technology have fundamentally changed managerial monitoring. No longer is the field sales manager cut off from his geographically dispersed sales personnel as e-monitoring allows continual rather than intermittent views of a wide range of indicators with copious detail. Given this change in monitoring, we examined the possible effect it may have on customer orientation. Conceptually, customer orientation levels should be enhanced when e-monitoring purposes serve informational purposes and be impeded with controlling purposes. We gathered responses from field salespeople employed in the manufacturing sector and found some support for these expected effects. Customer orientation levels are higher when the predominant purpose of e-monitoring is to provide information. Thus efforts on the part of the manager to clarify the fact that e-monitoring is predominantly serving informational purposes will be worthwhile.

Contrary to expectations our HLM moderator analyses indicate the reaction to either control or inform purposes in a very bureaucratic culture is less dramatic than that expressed in a less bureaucratic one. In low -rather than high -bureaucratic cultural contexts, informing attributions help and controlling hurt customer orientation. A firm which is not highly bureaucratic but uses e-monitoring as a control mechanism, then it may be giving mixed messages to the salesperson with a resultant level of confusion and lack of customer-orientation. A firm which is not highly bureaucratic and uses e-monitoring to empower or inform may be more focused and effective in gaining higher levels of customer orientation from their field salespeople.
\end{abstract}


Currently sales information systems give managers an unprecedented access to salesperson activities via electronic monitoring, or e-monitoring. Pharmaceutical firms, for example, record and analyze the frequency with which each salesperson is using CRM software (Ahearne et al. 2004). Firms such as Purewiere and Zscaler are part of this growing 'awareness technology' and offer products that extend the sales manager's reach to monitor field salespeople outside the company network (The Economist 2009; Needleman 2010). Technology has fundamentally changed sales management monitoring (i.e. from intermittent to continual, from a restricted to unrestricted range of indicators) (Ball 2010).

These changes in technology have been accompanied by major changes in the nature of the personal selling process (Sharma 2007; Verbeke et al 2011). Customers are better informed, more demanding and these challenges require salespeople to go beyond the simplistic sales tactics to a deeper level - one in which the salesperson internalizes customer-oriented values. Given the unique characteristics of the field sales setting, this deeper level of motivation may be more problematic. Distance and complexity are two unique characteristics that differentially affect their perceptions and reactions (Challagalla et al 2000; Stanton and Weiss 2000). Specifically, the perceived reasons behind managerial monitoring are formed through a more distant lens and one which is frequently clouded by task ambiguity and complexity (Aiello 1993; Aiello and Svec 1993). In the face of these challenges and changes, what happens to a salesperson's motivation to do so, to internalize the values of being customer oriented under the scrutiny of e-monitoring?

While monitoring may increase compliance with ethical standards it may decrease still other more desirable customer-oriented behaviors (Bush, Bush and Orr 2010). Numerous SFA studies discuss this possibility but none to date have explicitly tested for this effect (Moutot and Bascoul 2008; Speier and Venkatesh 2002; Sundaram, Schwarz, Jones and Chin 2007). Thus the purpose of this study is to test the effect of emonitoring on the customer orientation of field salespeople. To that end we employ the conceptual framework offered by self-determination theory.

Self-determination theory (SDT) focuses on explaining the deep level of motivation required to address the challenges of customer-oriented behaviors (Stone, 
Deci and Ryan 2008). Customer oriented behaviors require substantial effort, time and commitment and the accompanying sustainable, enduring level of motivation (Homburg et al 2011). In order for motivation to be enduring, the salesperson must feel his or her actions are self-selected, reflect their own choices and are volitional. If e-monitoring is perceived to be an impediment to these feelings, it is not likely customer-oriented values will be internalized. Because these perceptions are formed within organizational contexts, our study tested the moderating effect of organizational culture (Harris and Ogbonna 2006). Importantly, organizational culture may play a key role in salespersons' reactions and perceptions regarding e-monitoring. An understanding of the organizational culture as a context could, for example, provide managers and researchers with deeper insights regarding the types of organizations in which e-monitoring might be effective.

\section{Self-Determination Theory and E-Monitoring}

Self-determination theory (SDT) contends motivation will be driven by the need to feel both competent and autonomous (Vansteenkiste et al 2010). These core psychological needs (i.e. competency and autonomy) must be met in order for employees to go beyond compliance to more proactive behavior reflected when values are internalized (Morhart et al 2009). Satisfying both needs creates sustainable, enduring motivation such as that required to internalize customeroriented values. Sustainable motivation is called autonomous because it emerges from one's sense of self and is accompanied by feelings of willingness and engagement (Baard et al 2004; Gagne et al 2000). Accordingly employees are constantly evaluating stimuli (such as managerial e-monitoring) to determine the degree to which it meets the core psychological needs of competence and autonomy (Gagne and Deci 2005; Ryan and Connell 1989).

An integral part of self determination theory (SDT), therefore is the salesperson's perceived reasons managers engage in e-monitoring. If the salesperson believes e-monitoring is serving developmental purposes rather than prescribing one course of action then competency and autonomy needs are being met. Competence is the belief that one has the ability to influence important outcomes. Autonomy concerns the experience of acting with a sense of choice, volition and self-determination. Efforts to control the actions of the salesperson reduce feelings of autonomy - and thus decrease motivation. Actions which build task-related abilities or skills increase feelings of competency - and thus increase motivation. Both needs are equally 
important and must be met for a salesperson to be motivated in their pursuit of customer-oriented selling (Deci, Connell and Ryan 1989).

Computer performance monitoring studies indicate employees put importance on the purposes of the electronically collected data (Stanton and Weiss, 2000). SDT claims these purposes can be classified as those which seek to inform the salesperson or those which seek to control the salesperson. When the predominant purpose behind e-monitoring is informational, this effort is seen as providing timely and accurate details to aid salesperson decisions. Controlling purposes, on the other hand, pressure the salesperson to use a prescribed course of action and focus on end-results. Controlling attributions thwart the need for autonomy while informational attributions help meet competency needs. In the subsequent sections we integrate sales management and computer-based performance monitoring literature into the selfdetermination theory framework to suggest the effect each of these attributions (informing and controlling) may have on customer orientation.

\section{Informational and Controlling Purposes: Examples and Effects}

An informational event provides behaviorally relevant data aimed at helping the salesperson improve their skills and abilities. An e-monitoring system which places emphasis on informational attributions would format the external report generator (i.e. a function on SFA programs such as ACT!) such that the salesperson only needs to update it and would select appropriate comparisons or benchmarks. Another example of an informational purpose may be lead scoring capabilities (Dunne 2010). Lead scoring provides the type of analyses that helps the salesperson make decisions concerning pursuit of leads. When these examples of e-monitoring are perceived to be serving the purposes of helping the salesperson decide they are seen as serving informational purposes.

When e-monitoring is perceived to be informational, it provides actionable methods to achieve customer-oriented competence (Alder and Ambrose, 2005; Shalley and Perry-Smith, 2001). Meta-analytical studies of SDT research confirm informational attributions have a strong and pronounced effect on feelings of competency and autonomy (Deci, Koestner and Ryan 2001; Haggar and Chatzisarantis 2009). We build on this body of findings to discuss how these proven relationships may affect salesperson customer orientation

Competency in adaptive selling behaviors is a precursor to customer orientation (Franke and Park 2006). Adaptive selling behaviors require the salesperson to be highly knowledgeable, 
to offer expertise and to understand the customers' problems (Homburg, Muller and Klarmann 2011; Stock and Hoyer 2005). Adaptive selling requires the competency to make appropriate and "on the spot" changes to a sales presentation and to customize the sales proposal (Roman and Icobucci 2010). Making these changes for each customer and during each sales call is part of working smart, can be learned, and informational inputs help the salesperson do just that. An emonitoring system which serves predominantly informational purposes would give the salesperson the 'dashboard' function so the salesperson can examine multiple gauges. These gauges can confirm or help the salesperson select a redirection of effort to increase competency. Because informational attributes meet adaptive selling-related competency needs, the salesperson will be more likely to internalize customer-oriented values.

Informational purposes leverage the data to help the salesperson make their own decisions. Thus informational attributions increase feelings of autonomy (Gagne and Bhave 2011). An e-monitoring system that predominantly serves informational purposes would be characterized by open access and flexible data reporting formats. These two characteristics to permeate both the sales manager-employee interface to the salesperson-customer interface (Jayachandran et al 2005). In effect then informational attributions empower salespeople to engage in autonomous decision making. A salesperson who feels the e-monitoring system is predominantly serving informational purposes has sufficient data at hand to make appropriate decisions at the point of customer interaction - and can adapt, can act independently in response to current customer needs. Because autonomy and competency needs are being met (when emonitoring is perceived to predominantly serve informational purposes) and are needed for the salesperson to adopt a customer orientation we expect the following:

\section{H1: A salesperson's perception that the IT system is serving informing purposes will increase the level of salesperson customer orientation.}

Unlike informational events, controlling events prescribe a course of action. For example e-monitoring attempts to control the learning behaviors of salespeople through use of software (i.e. LaunchForce) to identify and prompt non-users of an online product training module (Weinreb 2002). Some firms even withhold compensation when a salesperson does not use the prescribed forms of software (e-Manager 2002; Tynan 2006). Controlling forms of e-monitoring also can include the mining of e-mails for keywords and screenshot capturing (e.g. track time spent accessing specific software or databases and even keystrokes) (Alaniz 2010). These forms 
of e-monitoring are intended to achieve conformity, to obtain compliance with specific behaviors and thus fit the definition of serving a controlling purpose.

If the salesperson believes e-monitoring is predominantly serving the purposes of control, feelings of autonomy will suffer. Controlling events are seen as pressure to attain a specific outcome in a prescribed manner and thus reduce the autonomous choices of the salesperson. This negative effect of controlling attributions on experienced autonomy is well documented in metaanalytical studies of both self-determination theory and e-monitoring studies (Carroll 2008; Haggar and Chatzisarantis 2009). Under controlling attribution conditions, the salesperson motivation is more externally than internally oriented. Controlling events co-opt choice and result in reduce feelings of autonomy (Phillips and Lord 1980; Ryan 1982). This causal relationship subsequently can decrease the likelihood an employee will internalize company values such as customer orientation (Ambrose and Kulik 1999; Deci et al., 2001).

When the purpose behind monitoring is control, compliance with structured rules is increased but at the expense of more complex problem solving volitional behaviors (Harris and Ogbonna, 2006). Given the nature of customer orientation, the potential negative effects emonitoring are troublesome. Customer orientation requires adaptability and the associated level of discretion, judgment, and flexibility on the part of the salesperson. E-monitoring systems constrain responses and limit solutions (Douthitt and Aiello, 2001; Zweig and Webster, 2002). When monitoring is performed for controlling purposes, participants in problem-solving experiments tend to generate fewer options (Shalley and Perry-Smith 2001).

This stream of logic implies controlling attributions on the part of the salesperson will result in lower autonomy and the salesperson will use less creativity or (at best) consider fewer options in responding to each customer's needs. Sales management literature supports this notion as studies concerning behavior-based control systems (of which e-monitoring are thought to be a component) impede effective use of SFA (Johnson and Bharadwaj 2005) as well as customer service levels (Onyemah, Rouzies and Panagopoulos 2010). This effect may be in part due to the findings within both sales management and SDT research streams that suggest monitoring hampers innovative or creative responses to customer problems (Dew 2009; Liu, Chen and Yao 2011; Matsuo 2009).

Additionally, controlling attributions may be undermining the salesperson's need to feel competent since they imply the salesperson discretion is less effective than those prescribed 
selling behaviors (Greguras and Diefendorff 2009). These affective reactions or feelings are highly influential and outweigh other factors in determining customer orientation (Joshi and Randall (2001). To the degree these feelings included those of both competence and autonomy, we may expect the following:

\section{H2: A salesperson's perception that the IT system is serving control purposes will decrease the level of salesperson customer orientation.}

\section{Organizational Culture as Moderators}

Because both attributions are being made at the same time, the effect of these attributions may be strengthened or weakened by the culture of the sales organization. Differential effects can be heightened given cultural contexts. We examine two such contexts: supportive and bureaucratic organizational cultures. Supportive organizational cultures emphasize trust and equity, and place value on interpersonal relationships (Wallach, 1983). The cultural value placed on trust suggests the primary purpose behind technology will be the salesperson's self-evaluation and skill development, rather than managerial control. Support for these agency theory notions is implied in sales information systems studies examining the effect of supportive sales manager behavior, with results revealing a positive link between supportive sales manager behaviors and salesperson technological competence and use (Mathieu et al., 2007; Schillewaert et al., 2005).

Supportive leader behaviors encourage the use of the same technology capable of monitoring performance. Salespeople may, in part, use, adopt and even infuse information technology because the supportive culture facilitates informative attributions. Supportive cultures tend to provide autonomy and discretion to their boundary spanners (Perrone et al., 2003). It is this type of culture, i.e., one characterized by cooperation and information sharing, that is most likely to lead to effective use of sales information tools (Pullig et al., 2002). In their study of a pharmaceutical sales force, Ahearne et al. (2008) found higher frequency of technology usage resulted in higher levels of salesperson adaptability and customer-rated service levels. This result, i.e., high technology use leading to more adaptability and customer service, requires the salesperson to use the sales information system communicate with or analyze customers actively and independently (Hunter and Perreault, 2006, 2007). Because supportive cultures place emphasis on the salesperson's autonomous use of IT systems to communicate and 
analyze, we would expect informing attributions made in a supportive cultural environment to yield even higher levels of customer orientation.

\section{H3: A supportive organizational culture will strengthen the positive effect of salesperson informing attributions on customer orientation.}

Theoretically, controlling attributions are still being made in supportive cultures. In the educational setting, studies suggest the supportive classroom context does not eliminate perceptions of controlling intent, although it does reduce the likelihood it will be seen primarily as controlling (Deci and Ryan, 1985). Conceptually, these attributions are being made by the employee to meet both competence and autonomy needs. Practically, an employee-even in a supportive organizational culture - realizes extrinsic rewards are accompanied by managerial control. In their study of IBM field technical support staff, Deci et al. (1989) observed that frequently attempts by management to be supportive were perceived to be controlling, in that positive feedback emphasized how employees should behave. Further, this study found even after intervention aimed at increasing the supportive climate, feelings related to being pressured or controlled still existed, and were unchanged. Thus, controlling attributions will still exist in supportive cultures.

Controlling attributions formed in the supportive organizational culture will not have the same effect on customer orientation as informing attributions. Because supportive learning environments enhance intrinsic motivation and skill development over the achievement of immediate extrinsically oriented outcomes (Deci et al., 2001), the effect of managerial control is less likely to restrict customer orientation. While controlling attributions are being made in the supportive organizational culture, the negative affect these attributions have on autonomy, selfdevelopment and the engagement in volitional customer oriented behaviors will be ameliorated. Because salesperson trust levels are higher in supportive climates, the salesperson will not feel threatened or restricted by controlling attributions (Druskat and Wheeler, 2003). Consistent with SDT, controlling attributions should lessen autonomy and the feeling of being self-directed. These lower levels of autonomy and self-determination, however, are more likely to be seen as appropriate oversight and possibly a welcomed level of transparency in customer-interactions (Harris and Ogbonna, 2006). Thus, lower levels of autonomy associated with controlling 
attributions interact with supportive culture to lessen the negative impact of controlling attributions. Accordingly, the following hypothesis is proposed.

\section{H4: A supportive organizational culture will counteract the negative effect of salesperson controlling attributions on customer orientation.}

In their comparison of highly structured or bureaucratic firms to those organizations which support adaptability, van Vuuren et al. (2008) found significant differences in employee commitment. To the degree that professionalism of a salesperson carries with it a commitment to solving customer problems and being customer oriented, we might expect the same pattern. Selfdetermination research confirms this expectation as it has shown informing or controlling attributions will interact with supportive cultures differently than bureaucratic cultures (Greguras and Diefendorff 2009).

When bureaucratic cultures deploy information systems they tend to do so with an emphasis on security, order and routinization rather than open access (Iivari and Huisman, 2007). In the retail service sector this bureaucratic treatment of IT limits the perceptions of empowerment (Kelley et al., 1993). In the field sales setting, Moutot and Bascoul (2008) found control activities, such as generating call reports, were inversely related to more customeroriented activities, such as using IT to plan the sales call or to generate proposals. When more bureaucratic organizations make demands on their field sales force to generate the controloriented reports, then one may expect these activities lead to a deterioration of customer orientation.

Bureaucratic organizational cultures emphasize structures, regulations, and procedures (Wallach, 1983). This type of culture emphasizes control, stability, and efficiency through following regulations (Iivari and Huisman, 2007). Given the emphasis on both structure (i.e., hierarchical "top-down") and control, computer surveillance in this organizational climate may be seen as serving the needs of the manager. Gohmann et al. (2005), for example, found army officers, and not their subordinates, felt close computer monitoring was productive. This discrepancy of opinions suggests salespeople in bureaucratic cultures are more likely to attribute the purpose behind computer monitoring to be managerial, external, and controlling. Because this bureaucratic culture is heavily control-oriented, electronic surveillance is likely to intensify a restrictive atmosphere (Aiello, 1993). This restrictive atmosphere may extend to perceptions 
concerning other attributions, such as those surrounding the degree to which data gathered through the sales system is being used for control purposes.

\section{H5: A bureaucratic organizational culture will strengthen the negative effect of salesperson controlling attributions on customer orientation.}

Since hierarchical structures characterize bureaucratic cultures, it is likely the information gathered through IT performance monitoring flows in that same hierarchical (i.e. vertical) direction. Thus, a salesperson in a bureaucratic culture will be reliant on his or her immediate supervisor for any comparative or summarized performance data. In a bureaucratic culture, one that typically places emphasis on security and restricts access, the salesperson may be less likely to feel he or she can use the system to improve his or her competency. In SDT terms, the salesperson working in a highly bureaucratic culture is less likely to feel the IT system is serving his or her informational needs. In their comparison of employee reactions to electronic monitoring Kidwell and Bennett (1994) found employees operating in a bureaucratic culture tended to feel less empowered. Accordingly, we expect the following.

\section{H6: A bureaucratic organizational culture will counteract the positive effect of salesperson informing attributions on customer orientation.}

\section{Methodology}

\section{Data Collection and Samples}

To create our sampling frame we generated a list of randomly selected manufacturing firms from the American Business Directory database. Those manufacturers who employed a geographically dispersed field sales force and made the investment in supplying their field salespeople with IT tools were deemed appropriate respondents for this study. Firms who agreed to participate were mailed a packet of materials for each of their salespeople. Responses were sent directly to university researchers to assure confidentiality. One reminder request was mailed to non-respondents three weeks later.

Two samples were generated using this method: one set for new scale development and another set for hypotheses testing purposes. The first scale development sample resulted in a response rate of $29.6 \%$ as 101 complete responses were received from the 341 distributed. The second data set was collected six months following the first and is based on 189 usable responses. The response rate for the second full-scale data collection effort was approximately $23.6 \%$ since 800 salesperson surveys were mailed. These two samples do not differ in terms of 
sales compensation method, experience, or education level of their sales force, nor in the size of each sales territory (Table 1). Although firms in these two samples do not differ in terms of these specific field sales issues (e.g., compensation, etc.), respondents in the second sample were employed with larger manufacturers. Since it is likely IT investments of smaller firms will differ from those of larger (and with those investments one might expect a lower level of sophisticated use of monitoring systems) we tested for differences between these two samples in IT usage and found samples shared similar levels of IT sophistication (Table 2).

Insert Tables 1 and 2 here

Additionally, we compared the profile of the companies employing respondents to that of nonrespondents. No proportional differences exist in terms of company size as indicated by the number of neither employees nor annual revenue. Further, we found no meaningful differences between our respondents and the population at large. These comparisons, i.e., respondents to nonrespondents' company size and respondents to general population, suggest these data are untainted by nonresponse bias.

\section{Measurement}

Building on the conceptual work within the self-determination theory stream of research, this study developed and pretested scales to measure informing and controlling attributions. Since informational and controlling attributions associated with managerial monitoring have been manipulated rather than surveyed, it was necessary to develop these measures (Deci et al 1989; Pittman et al 1980; Ryan 1982; Phillips and Lord 1980; Shalley and Perry-Smith 2001). Controlling attributions are defined as pressure to comply whereas informing attributions are defined as guidance in development. Consistent with these conceptual definitions, pools of items were created, edited, and culled for face validity. The resultant items were analyzed based on data collected from the first sample of salespeople $(n=101)$. Results from the first sample were supportive of each five-item scale. The internal reliability indicators (i.e., Cronbach's alpha and composite reliabilities) for informing attributions and controlling attributions were all above .80. Variance extracted exceeded recommended cutoffs and were .56 for controlling and .67 for informing attribution measures (Fornell and Larker, 1981). The factor loading for one of the control items was less than .40 and modification indices suggested deletion. Given the generally supportive overall results from a sample size of 101, we sought confirmatory information and 
collected more data. The results section describes these outcomes of the full-scale data collection effort.

Customer orientation, supportive culture, and bureaucratic culture were measured using previously developed and validated scales. Customer orientation was measured using the 5-item version suggested by Thomas et al. (2001) and validated by Periatt et al. (2004). These Likert items measured the practice of the marketing concept at the level of the individual salesperson and customer (Saxe and Weitz, 1982). The scales measuring organizational culture were drawn from Wallach (1983) have been validated in marketing applications (Akaah, 1993; Oliver and Anderson, 1994). Bureaucracy items measure the degree to which authority is hierarchical and tasks are systematically organized. Supportive culture items measure the degree to which the environment is harmonious and humanistic. Respondents indicated the applicability of each adjective. Adjectives describing supportive cultures included collaborative, trusting, equitable, encouraging, sociable, and relationship-oriented. Adjectives describing bureaucratic cultures included procedural, structured, regulated, hierarchical, and power-oriented. Using a 4-point scale, respondents rated the degree to which each adjective described the organization.

The six hypotheses were tested using hierarchical linear modeling. The main effects model tested the first two hypotheses. A comparison of regression models was used to identify pure moderators (testing Hypotheses 3, 4, 5 and 6). A pure modifier exists when a series of unfolding regression questions rule out direct effects of the moderator variables (i.e., bureaucratic or supportive culture) then demonstrate meaningful incremental effects of including the interaction terms.

Measurement Results. Informing and controlling attributions scale properties suggested in the pretest data analyses were subject to additional analyses in the full-scale data set. Initially we compared the five item scale results to those of the pretest. Full-scale data analyses confirmed pre-test results of weak or marginal loadings. Given these confirmatory pre-test results, one item was deleted from each informing and controlling attribution measure. Deletion of items with loadings of less than .60 purified this scale to provide acceptable levels of internal reliability (i.e., composite reliabilities $>.75$ ). The variance extracted using these items were .55 for controlling attributions and .54 for informing attributions. The measurement model statistics met recommended cutoffs, with the GFI=.98, AGFI=.95, Chi-Square=11.14 $(\mathrm{df}=8), \mathrm{RMSEA}=.045(\mathrm{Hu}$ and Bentler, 1999). Results support convergent validity for the measures as the t-values of all of 
the items' estimated loadings on their related constructs are significant. Both variance extracted estimates are greater in magnitude than the squared correlations, providing evidence of discriminant validity between the informing and controlling attribution measures. The unconstrained measurement model fit the data better than the constrained measurement models. This comparison resulted in significantly higher Chi-squares with the unidimensional model over the standard model at a probability level less than .0001 .

Scale properties of the previously developed and validated measures (e.g., supportive organizational culture, bureaucratic organizational culture, and customer orientation) fell within acceptable ranges. (See Table 3) CFA models overall fit indices were satisfactory, with GFI values exceeding .90 (i.e. range of GFI values .95 to .99 ). The low levels of standardized root mean square an error (.03 to .07), which implies each set of observed indicators was measuring the intended latent concept.

Each of these previously developed and validated scales with one exception exhibited acceptable levels of variance extracted. The exception was bureaucratic culture, for which variance extracted did not exceed the recommended .50 cutoff value. Nevertheless, we did not modify the scale because it has been previously validated, and because we sought to retain the theoretical meaning of the construct. As a precaution, however, we verified the discriminatory validity of the bureaucratic culture scale. Measurement models in which both supportive and bureaucratic culture items loaded on separate latent factors was a substantially improved fit over a model stipulating one latent factor. Comparisons of models in which covariances were constrained to those in which covariances were estimated indicate bureaucratic culture is a distinct construct. The shared variance between pairs of constructs was less than the average variance extracted (Fornell and Larker, 1981).

Finally, all standardized loadings from the CFA analyses were above the .50 levels and significant providing evidence of convergent validity (Table 3). Overall, the CFA models indicated that our constructs possessed satisfactory psychometric properties. -Insert Table 3 here-

Common method variance could bias the findings when both dependent and independent variables are assessed from the same salesperson, as in the case of this study. To gauge the impact, if any, of common method bias we examined factor structures and marker variables. 
Principal component factor analyses of all indicators used in this analysis extracted a five-factor solution (five factors had eigenvalues greater than one and total variance explained more than sixty percent). These results suggest that variance may be reflected in the five variables of interest rather than heavily influenced by the extraction of one highly influential common factor. Additionally, we used a marker variable as an estimate of possible common method variance (Lindell and Whitney, 2001). The marker variable was selected based on both empirical and conceptual criteria. The size of the firm met both conceptual and empirical criteria; the number of employees was used as a marker variable. This process requires that partial correlations, i.e., partialing out the effect of this marker variable, be compared to the original correlation matrix. If the pattern of significant correlations changes, this may imply the existence of common method variance. This comparison of partial to original correlations (Table 4) provides further evidence of the lack of common method variance. Based on the factor structure and the marker variable analyses we may conclude the risk of common method bias is not inflating the relationships found in this study (Lindell and Whitney, 2001).

Insert Table 4 here

\section{Hierarchical Linear Models}

Table 5 reports the results of the hierarchical linear modeling analysis. As shown, informing and controlling attributions predicted $8.3 \%$ of the variation in customer orientation. The overall F-statistic of a model testing this predictive ability of informing and controlling attributions was $8.47_{(2,186)}$. The significance associated with the informing attribution parameter estimates supports $\mathrm{H} 1$; that is, a salesperson's perception that the IT system is serving informing purposes appears to increase the level of customer orientation. The standardized estimate of .27 of informing attributions was significant at a probability level of less than .0001 . While the standardized parameter for controlling attributions is negative, analyses here indicate the main effect is not significant. Thus, H2 is not supported; a salesperson's perception that the IT system is serving controlling purposes does not appear to decrease that salesperson's level of customer orientation.

A series of unfolding regression analyses examined the effects of a pure moderator. This series tested for: (1) main effects of the predictor variables only, (2) main effects of both predictor and moderator variables, and finally, (3) a full model, including all main effects and 
hypothesized interaction effects. A pure moderator exists when three conditions are met: the moderator variable does not have a direct effect on the criterion nor does it relate significantly to the predictor variables, and adds significantly to the prediction when combined with the predictor variable(s) (Sharma et al., 1981). Thus, we compared the direct effects of two regressions to rule out the possibility that the two culture variables were incrementally explaining variability in customer orientation. Table 5 shows this first comparison of the two main effects models; one testing the main effects of just informing and controlling attributions to one testing main effects of both attribution variables and both culture variables. The inclusion of direct effects of culture variables did not substantially reduce the sum of square errors as the F-statistic of $1.64_{(2,184)}$ with associated probability of .195. Informing attributions remain significant and controlling attributions remain non-significant in the second main effects model, and parameter estimates for supportive and bureaucratic culture variables are not significant. Thus, we could rule out these two measures of culture as quasi-moderators.

The comparisons of each main effect models to the full model indicate significant reductions in sum of square errors (see Table 5, comparisons noted $\Delta_{2}$ and $\Delta_{3}$ ). The F-statistics of 5.47 and 4.25 , comparing reduced main effects to main effects with moderator variables respectively, were significant at probability levels less than .001 . These results show the inclusion of interaction terms combining attributions with culture do add predictive power to explain customer orientation levels. Culture appears to qualify as a pure modifier and does interact with attributions to explain customer orientation. This full model was able to explain $11.36 \%$ more variability in customer orientation than the complete main effects model.

-Insert Table 5 here

Examination of the significant interaction terms indicates bureaucratic culture moderates both forms of attributions but supportive cultures do not. Supportive cultures do not amplify positive effects of informing attributions $(\beta=.003, \mathrm{t}=.20)$ nor nullify negative effects of controlling attributions $(\beta=.003, \mathrm{t}=.19)$. While the hypotheses concerning the strengthening $\left(\mathrm{H}_{3}\right)$ and weakening $\left(\mathrm{H}_{4}\right)$ effect of supportive culture are not supported by this analyses, results here indicate culture does have a moderating effect.

Bureaucratic culture has a significant effect on the degree to which either of these attributions affects customer orientation. The interaction term measuring the combined effect of bureaucratic culture and controlling attributions is significant with a parameter estimate of .05 
$(\mathrm{t}=2.61)$. When controlling attributions are being made within a highly bureaucratic cultural context, they do hurt customer orientation, but not with the same deleterious affects as lower levels of bureaucracy. We expected that the negative effect of controlling attributions on customer orientation would be more pronounced under the conditions of bureaucratic culture (H5). Results here do support the notion that bureaucratic culture does make a difference and to that end results are partially supportive. The direction of this effect, however, runs counter to the expected amplifying effect. This amplified negative effect is more pronounced under low bureaucratic conditions rather than higher bureaucratic cultures (Figure 2). When organizational culture is less bureaucratic, controlling attributions have a more negative effect on customer orientation. At higher levels of bureaucratic culture, controlling attributions have a moderately negative impact on customer orientation. When informing attributions are made in a highly bureaucratic culture, these attributions tend to have less of a positive effect on customer orientation. The parameter estimate for this interaction term, i.e., bureaucratic culture $\mathrm{x}$ informing attributions, was $-.08(\mathrm{t}=-3.84)$. Under low bureaucratic cultures, informing attributions share a positive linear relationship with customer orientation. When those same attributions take place in highly bureaucratic cultures their ability to improve customer orientation is dramatically lessened (Figure 2). Support is attained for H6, as bureaucratic culture weakens the ability of informing attributions to enhance customer orientation.

-Insert Figure 2 here

\section{Discussion}

Sales managers will continue to use e-monitoring and struggle with concerns about its ability to increase accountability and decrease empowerment. Our results help managers find the balance by suggesting three courses of action. First, managers should discuss openly the purposes of e-monitoring with their salespeople. This open discussion may reduce any misattributions (i.e a salesperson suspecting that the system is being used to control rather than inform). Managers can increase the reality and the perception that e-monitoring systems are predominantly serving the purposes of guiding and empowering salesperson decisions. When these discussions are collaborative and salesperson input is welcomed into the e-monitoring process, autonomy needs are being met. When, for example functions such as external report generating (i.e. ACT!) are appropriately formatted and easily accessible, it is highly likely e- 
monitoring may not be solely a managerial task but a self-monitoring one as well. We found emonitoring purposes which allow the salesperson to make their own task-related decisions will enhance customer orientation. The effect of using e-monitoring to limit salesperson decisions, however, can be exacerbated by the cultural context and thus we offer a second managerial recommendation.

Managers should consider the degree to which e-monitoring is consistent with other control elements. When salespeople believe e-monitoring is serving predominantly a controlling purpose - and they are doing so in a low bureaucratic culture, this may be sending mixed messages to salespeople. When structure is unclear and the bureaucratic context is not well defined the salesperson reacts differently to more controlling attributions (i.e. to the belief that emonitoring is being done to dictate selling behaviors). This reaction is one of reduced levels of customer orientation. In effect the salesperson may not be internalizing customer-oriented values because of these inconsistencies. The combination of more controlling attributions in the face of lower levels of bureaucratic culture does not send a consistent message to the salesperson - and lacking this message the salesperson cannot fully internalize it. When, however, the salesperson operating in a culture that places less emphasis on regulating procedures believes this intent (i.e. less emphasis on regulating selling procedures) is reflected in the informational purposes behind e-monitoring, then a more consistent message is being sent by the organization to their boundary spanning field salespeople. Customer orientation is more likely to be internalized by field salespeople when informing attributions are culturally consistent (i.e. low levels of bureaucracy).

Finally, managers should seek e-monitoring systems that do not place the burden on salespeople. Our results suggest salespersons' fears that IT will reduce empowerment are likely to interact with any additional administrative burdens such as those found in a bureaucratic culture. To the degree that more bureaucratic organizations place more emphasis on administrative duties, one is likely to find salespeople fear loss of empowerment in these organizational cultures. Our results suggest other externally-oriented tasks, such as those consistent with customer orientation, will suffer.

\section{Study Limitations and Future Research}


While results support the SDT notion that informational attributions will help customer orientation and culture acts as a moderator, we did not find supportive culture to be a one of those significant moderators. Contrary to expectations supportive environments do not amplify positive effects of informational attributes nor suppress negative effects of controlling attributions. Perhaps supportive cultures place too much emphasis on internal relationships and developing affect (e.g. employee satisfaction) over task (e.g. employee achievement). The field salesperson may need more externally focused structure (rather than internally focused support) to effectively cross the organizational boundaries. Given customer oriented behaviors are more resource intensive - and do not always result in better performance, salespeople may need more guidance in the form of recommendations (rather than just trusting their judgment or encouraging risks of investing more time in some accounts which will not respond eventually to these forms of customer oriented investments. (Homburg et al 2011).

As mentioned previously, the variance extracted value for the bureaucratic culture measure did not exceed the .50 cutoff recommended by Fornell and Larcker (1981). To examine the issue more fully, we conducted post hoc analyses to examine the possibility that bureaucratic culture may have underlying dimensions that are enabling as well as coercive. Exploratory factory analysis findings supported this notion, revealing two dimensions: one consisting of items related to enabling processes or behaviors (i.e., procedural, regulated, and structured) and one consisting of items more representative of coercive processes or behaviors (i.e., poweroriented, hierarchical, and pressurized). Given this finding, we conducted the HLM analyses with the enabling dimension versus the coercive dimension. We found no meaningful differences in our results using these measures. The nomological network surrounding the bureaucratic measures used in this study appears valid. Still, future research investigating the underlying dimensions of bureaucratic cultures may be worthwhile. Measures that tapped these dimensions of bureaucracy may add depth to our understanding of the effect of this form of culture in the boundary-spanning context.

The results of the present study demonstrate the effects of e-monitoring on customer orientation. Yet other outcome variables may also be worthy of investigation. Of particular interest is whether e-monitoring closes the geographical gap between the manager and the salesperson. In a study comparing remote salespeople to proximally close salespeople, Challagalla et al. (2000) found that remote salespeople were more likely to be satisfied with a 
supervisor with an activity orientation, i.e., a supervisor who tends to engage in the monitoring of salespeople, among other activities; the same effect was not found for proximally close salespeople. In their suggestions for future research, Challagalla et al. (2000) recommend testing whether IT can compensate for these differences in results. We echo this call for additional research examining the effect of e-monitoring on outcomes rising from the physical distance between sales manager and salesperson. 
Table 1

Sample Profile Comparison

\begin{tabular}{|c|c|c|c|c|}
\hline \multirow[b]{2}{*}{ Overall MANOVA (testing for all six variables), $F=1.82(p=.09)$} & \multicolumn{2}{|c|}{$\begin{array}{c}\text { Sample } 1 \\
n=101\end{array}$} & \multicolumn{2}{|c|}{$\begin{array}{c}\text { Sample } 2 \\
n=189\end{array}$} \\
\hline & \# & $\%$ & \# & $\%$ \\
\hline \multicolumn{5}{|l|}{ Sales Compensation } \\
\hline Straight Salary & 44 & 39.7 & 46 & 24.3 \\
\hline Straight Commission & 13 & 11.7 & 54 & 28.6 \\
\hline Combination & 54 & 48.6 & 89 & 47.1 \\
\hline \multicolumn{5}{|l|}{ Number of Customers in Salesperson's Territory } \\
\hline$<25$ accounts & 22 & 20.4 & 31 & 16.5 \\
\hline $25-100$ accounts & 40 & 37.0 & 77 & 41.0 \\
\hline $101-200$ accounts & 18 & 16.7 & 45 & 23.9 \\
\hline 201 or more accounts & 28 & 25.9 & 35 & 18.6 \\
\hline \multicolumn{5}{|l|}{ Annual Company Revenue ${ }^{a}$} \\
\hline$\$ 2.5-5$ million & 19 & 17.6 & 13 & 7.0 \\
\hline$\$ 5-10$ million & 10 & 9.3 & 24 & 13.0 \\
\hline$\$ 10-20$ million & 20 & 18.5 & 59 & 31.9 \\
\hline$\$ 20-50$ million & 54 & 50.0 & 39 & 21.1 \\
\hline$\$ 50-100$ million & 5 & 4.6 & 30 & 16.2 \\
\hline$\$ 100-500$ million & 0 & 0.0 & 20 & 10.8 \\
\hline \multicolumn{5}{|l|}{ Total Number of Employees ${ }^{a}$} \\
\hline $20-49$ & 40 & 39.6 & 52 & 27.5 \\
\hline $50-99$ & 23 & 22.8 & 59 & 31.3 \\
\hline $100-249$ & 24 & 23.8 & 25 & 13.2 \\
\hline $250-499$ & 14 & 13.8 & 49 & 25.9 \\
\hline $500-999$ & 0 & 0 & 4 & 2.1 \\
\hline \multicolumn{5}{|l|}{ Salesperson's Experience with Firm } \\
\hline$<1$ year & 5 & 4.4 & 11 & 5.9 \\
\hline $1-3$ years & 28 & 25.0 & 33 & 17.6 \\
\hline $4-6$ years & 22 & 19.6 & 35 & 18.7 \\
\hline $7-9$ years & 17 & 15.2 & 22 & 11.8 \\
\hline $10-12$ years & 6 & 5.4 & 22 & 11.8 \\
\hline $13-15$ years & 6 & 5.4 & 15 & 8.0 \\
\hline 16 or more years & 28 & 25.0 & 49 & 26.2 \\
\hline \multicolumn{5}{|l|}{ Salesperson's Education } \\
\hline High School & 18 & 16.1 & 27 & 14.4 \\
\hline Some College & 41 & 36.6 & 57 & 30.3 \\
\hline College Degree & 47 & 41.9 & 75 & 39.9 \\
\hline Some Graduate School & 3 & 2.7 & 14 & 7.4 \\
\hline Graduate Degree & 3 & 2.7 & 15 & 8.0 \\
\hline
\end{tabular}


Table 2

Comparison of Sales Information System Characteristics

\begin{tabular}{|c|c|c|c|c|c|}
\hline \multicolumn{6}{|c|}{ Overall MANOVA F=1.91 (probability $=.11)$, Wilks Lambda $=.92$} \\
\hline Variable & Definition & Method of Scoring ${ }^{a}$ & Sample $^{\text {b }}$ & Mean & Std. Dev. \\
\hline \multirow[t]{2}{*}{ Document Form } & Degree to which the sales information & Scored low for manual system, e.g., paper & 1 & 2.74 & 1.30 \\
\hline & $\begin{array}{l}\text { system uses documents in paper versus } \\
\text { electronic forms. }\end{array}$ & $\begin{array}{l}\text { based, and high for electronic, e.g., Web- } \\
\text { based. }\end{array}$ & 2 & 2.52 & 1.25 \\
\hline \multirow[t]{2}{*}{ Directional Flow } & Degree to which the computer network & Scored low for network system restricted to & 1 & 3.06 & 1.26 \\
\hline & $\begin{array}{l}\text { system allows many directional flows of } \\
\text { information. }\end{array}$ & $\begin{array}{l}\text { input only, e.g., field sales providing input to } \\
\text { headquarters, and high for a system allowing } \\
\text { both input and access by many departments. }\end{array}$ & 2 & 3.18 & 1.32 \\
\hline \multirow[t]{2}{*}{ Connectivity } & Degree of connectivity of the computer & Scored low for mainframe dependent system & 1 & 3.12 & 1.48 \\
\hline & network system. & $\begin{array}{l}\text { and high scores for systems using LAN or } \\
\text { Web to combine both personal and mainframe } \\
\text { computing. }\end{array}$ & 2 & 2.82 & 1.34 \\
\hline \multirow[t]{2}{*}{ Wireless } & Degree to which the personal computer & Score low for wired and high for wireless. & 1 & 2.54 & 1.01 \\
\hline & $\begin{array}{l}\text { communication system takes either } \\
\text { wired or wireless forms. }\end{array}$ & & 2 & 2.61 & 1.00 \\
\hline
\end{tabular}

\footnotetext{
${ }^{\mathrm{a}}$ Values ranged from $1-5$.

${ }^{\mathrm{b}}$ Sample $1 \mathrm{n}=101$, Sample $2 \mathrm{n}=189$.
} 
Table 3

Construct: Scale items and Properties

\begin{tabular}{|c|c|c|c|c|c|c|c|}
\hline Variable & Mean & $\begin{array}{l}\text { Std. } \\
\text { Dev. }\end{array}$ & Items & $\begin{array}{c}\text { Std. } \\
\beta\end{array}$ & $\boldsymbol{\alpha}$ & C.R. & Source(s) \\
\hline $\begin{array}{l}\text { Customer } \\
\text { Orientation }^{\mathrm{a}}\end{array}$ & 31.45 & 3.47 & $\begin{array}{l}\text { I try to bring a customer with a problem together with a product/service that } \\
\text { helps him/her solve that problem. } \\
\text { I try to figure out what a customer's needs are. } \\
\text { I try to find out what kind of product would be most helpful to a customer. } \\
\text { A good salesperson has to have the customer's best interest in mind. } \\
\text { I offer the product/service of mine that is best suited to the customer's } \\
\text { problem. }\end{array}$ & $\begin{array}{l}.79 \\
.71 \\
.61 \\
.59 \\
.76\end{array}$ & .82 & .82 & $\begin{array}{l}\text { Proposed: Thomas, } \\
\text { Soutar, and Ryan (2001) } \\
\text { Validated: Periatt, LeMay, } \\
\text { and Chakrabarty (2004) }\end{array}$ \\
\hline $\begin{array}{l}\text { Supportive } \\
\text { Culture }^{\mathrm{b}}\end{array}$ & 15.73 & 3.35 & $\begin{array}{l}\text { Relationship-oriented } \\
\text { Encouraging } \\
\text { Sociable } \\
\text { Equitable } \\
\text { Trusting }\end{array}$ & $\begin{array}{l}.66 \\
.84 \\
.81 \\
.71 \\
.67\end{array}$ & .85 & .86 & $\begin{array}{l}\text { Proposed: Wallach (1983) } \\
\text { Validated: Akaah (1993), } \\
\text { Oliver and Anderson } \\
\text { (1994) }\end{array}$ \\
\hline $\begin{array}{l}\text { Bureaucratic } \\
\text { Culture }^{\mathrm{b}}\end{array}$ & 13.47 & 3.13 & $\begin{array}{l}\text { Hierarchical } \\
\text { Procedural } \\
\text { Structured } \\
\text { Regulated } \\
\text { Power-oriented }\end{array}$ & $\begin{array}{l}.55 \\
.64 \\
.59 \\
.67 \\
.53\end{array}$ & .73 & .73 & $\begin{array}{l}\text { Proposed: Wallach (1983) } \\
\text { Validated: Akaah (1993), } \\
\text { Oliver and Anderson } \\
\text { (1994) }\end{array}$ \\
\hline $\begin{array}{l}\text { Informing } \\
\text { Attributions }\end{array}$ & 14.58 & 3.63 & $\begin{array}{l}\text { Information from my company's sales systems is used by management to } \\
\text { let me determine how well I am doing. } \\
\text { Management uses the information from our sales systems to monitor and } \\
\text { provide guidance in my selling efforts. } \\
\text { Information from my company's sales systems is used by management to } \\
\text { empower me in my selling efforts. }\end{array}$ & $\begin{array}{l}.63 \\
.81 \\
.72\end{array}$ & .76 & .76 & See Appendix B \\
\hline $\begin{array}{l}\text { Controlling } \\
\text { Attributions }^{\mathrm{a}}\end{array}$ & 9.84 & 3.85 & $\begin{array}{l}\text { Management uses the information from our sales systems to tell me what } \\
\text { specific selling behaviors I ought to be doing on my job. } \\
\text { Information from my company's sales systems is used by management to } \\
\text { point out to me when I am not using the right selling techniques. } \\
\text { Information from my company's sales systems is used by management to } \\
\text { tell me what specifically I should be doing on my job. }\end{array}$ & $\begin{array}{l}.65 \\
.83 \\
.73\end{array}$ & .78 & .78 & See Appendix B \\
\hline
\end{tabular}

${ }^{\mathrm{a}}$ Items measured on a 7-point Likert scale.

${ }^{\mathrm{b}}$ Items measured on a 4-point scale. 
Table 4

Correlation Matrix

\begin{tabular}{|c|c|c|c|c|}
\hline Variables: & Controlling & Supportive & Bureaucratic & $\begin{array}{l}\text { Customer } \\
\text { Orientation }\end{array}$ \\
\hline Informing & $\begin{array}{l}.32^{\mathrm{a}} \\
.32^{\mathrm{a}}\end{array}$ & $\begin{array}{l}.13 \\
.12\end{array}$ & $\begin{array}{l}.12 \\
.11\end{array}$ & $\begin{array}{l}.27^{\mathrm{a}} \\
.27^{\mathrm{a}}\end{array}$ \\
\hline Controlling & & $\begin{array}{l}-.18^{\mathrm{b}} \\
-.20^{\mathrm{a}}\end{array}$ & $\begin{array}{l}.18^{\mathrm{b}} \\
.18^{\mathrm{b}}\end{array}$ & $\begin{array}{l}-.05 \\
-.03\end{array}$ \\
\hline Supportive & & & $\begin{array}{l}-.18^{\mathrm{b}} \\
-.20^{\mathrm{a}}\end{array}$ & $\begin{array}{l}.01 \\
.02\end{array}$ \\
\hline Bureaucratic & & & & $\begin{array}{l}.17^{\mathrm{b}} \\
.17^{\mathrm{b}}\end{array}$ \\
\hline
\end{tabular}


Table 5

Results

\begin{tabular}{|c|c|c|c|c|c|c|c|}
\hline \multirow{2}{*}{ Variables } & \multirow[b]{2}{*}{ H } & \multicolumn{2}{|c|}{$\begin{array}{c}\text { Main Effects } \\
\text { (Reduced Model) } \\
\end{array}$} & \multicolumn{2}{|c|}{$\begin{array}{l}\text { Main Effects } \\
\text { (With Org. } \\
\text { Culture) }\end{array}$} & \multicolumn{2}{|c|}{$\begin{array}{c}\text { Main \& } \\
\text { Interactions } \\
\text { (Full Model ) } \\
\end{array}$} \\
\hline & & Std. $\beta$ & $\mathbf{T}$ & Std. $\beta$ & $t$ & Std. $\beta$ & $\bar{T}$ \\
\hline \multirow{2}{*}{$\begin{array}{l}\text { Constant } \\
\text { Informing Attributions }\end{array}$} & & -------- & 28.22 & -------- & 27.37 & ------- & 2.98 \\
\hline & $\mathbf{H}_{1}$ & .271 & $4.11^{\mathrm{a}}$ & .29 & $4.02^{\mathrm{a}}$ & 1.34 & $2.90^{b}$ \\
\hline \multirow{10}{*}{$\begin{array}{l}\text { Controlling Attributions } \\
\text { Supportive Culture } \\
\text { Bureaucratic Culture } \\
\text { Supportive*Info } \\
\text { Supportive*Control } \\
\text { Burcratic*Control } \\
\text { Burcratic*Info }\end{array}$} & \multirow[t]{3}{*}{$\mathbf{H}_{2}$} & -.103 & -1.55 & -.13 & -1.88 & -.92 & $-2.00^{c}$ \\
\hline & & --------- & --------- & -.04 & -.54 & -.08 & -.29 \\
\hline & & --------- & --------- & .13 & 1.61 & .69 & $2.35^{\mathrm{c}}$ \\
\hline & \multirow{7}{*}{$\begin{array}{l}\mathbf{H}_{3} \\
\mathbf{H}_{4} \\
\mathbf{H}_{5} \\
\mathbf{H}_{6}\end{array}$} & --------- & --------- & --------- & --------- & .00 & .20 \\
\hline & & --------- & --------- & ---------- & --------- & .00 & .19 \\
\hline & & --------- & -------- & -------- & --------- & .05 & $2.61^{\mathrm{c}}$ \\
\hline & & --------- & --------- & -------- & --------- & -.08 & $-3.84^{\mathrm{a}}$ \\
\hline & & $\mathrm{R}^{2}$ & .08 & $\mathrm{R}^{2}$ & .10 & $\mathrm{R}^{2}$ & .20 \\
\hline & & $\mathrm{F}$ & $8.47^{\mathrm{a}}$ & $\mathrm{F}$ & $5.09^{\mathrm{a}}$ & $\mathrm{F}$ & $5.53^{\mathrm{a}}$ \\
\hline & & d.f. & 2,186 & d.f. & 4,184 & d.f. & 8,180 \\
\hline & & \multicolumn{2}{|c|}{$\begin{array}{c}\Delta_{1} \\
\text { Comparison }\end{array}$} & \multicolumn{2}{|c|}{$\begin{array}{c}\Delta_{2} \\
\text { Comparison }\end{array}$} & \multicolumn{2}{|c|}{$\begin{array}{c}\Delta_{3} \\
\text { Comparison } \\
\end{array}$} \\
\hline & & $\Delta_{1} \mathrm{R}^{2}$ & +.02 & $\Delta_{2} \mathrm{R}^{2}$ & +.10 & $\Delta_{3} R^{2}$ & +.11 \\
\hline & & $\mathrm{F}$ & 1.64 & $\mathrm{~F}$ & $5.47^{\mathrm{a}}$ & $\mathrm{F}$ & $4.25^{\mathrm{a}}$ \\
\hline & & d.f. & 2,184 & d.f. & 4,180 & d.f. & 6,180 \\
\hline \multicolumn{2}{|c|}{ Test for Pure Moderator } & Yes & Not Sig. & Yes & Sig. & Yes & Sig. \\
\hline
\end{tabular}

${ }^{a} \mathrm{p} \leq .001$
${ }^{b} \mathrm{p} \leq .01$
${ }^{\mathrm{c}} \mathrm{p} \leq .05$

Note:

$\Delta_{1}$ Compares Main Effect (Reduced) to Main Effects (with moderator)

$\Delta_{2}$ Compares Main Effects (with moderator) to Main \& Interaction (Full Model)

$\Delta_{3}$ Compares Main Effect (Reduced) to Main \& Interaction (Full Model)

Pure Moderator exists when all three conditions are met: (1) $\Delta_{1}$ Not Significant

(2) $\Delta_{2}$ Significant

(3) $\Delta_{3}$ Significant 
Figure 1

Hypothesized Relationships
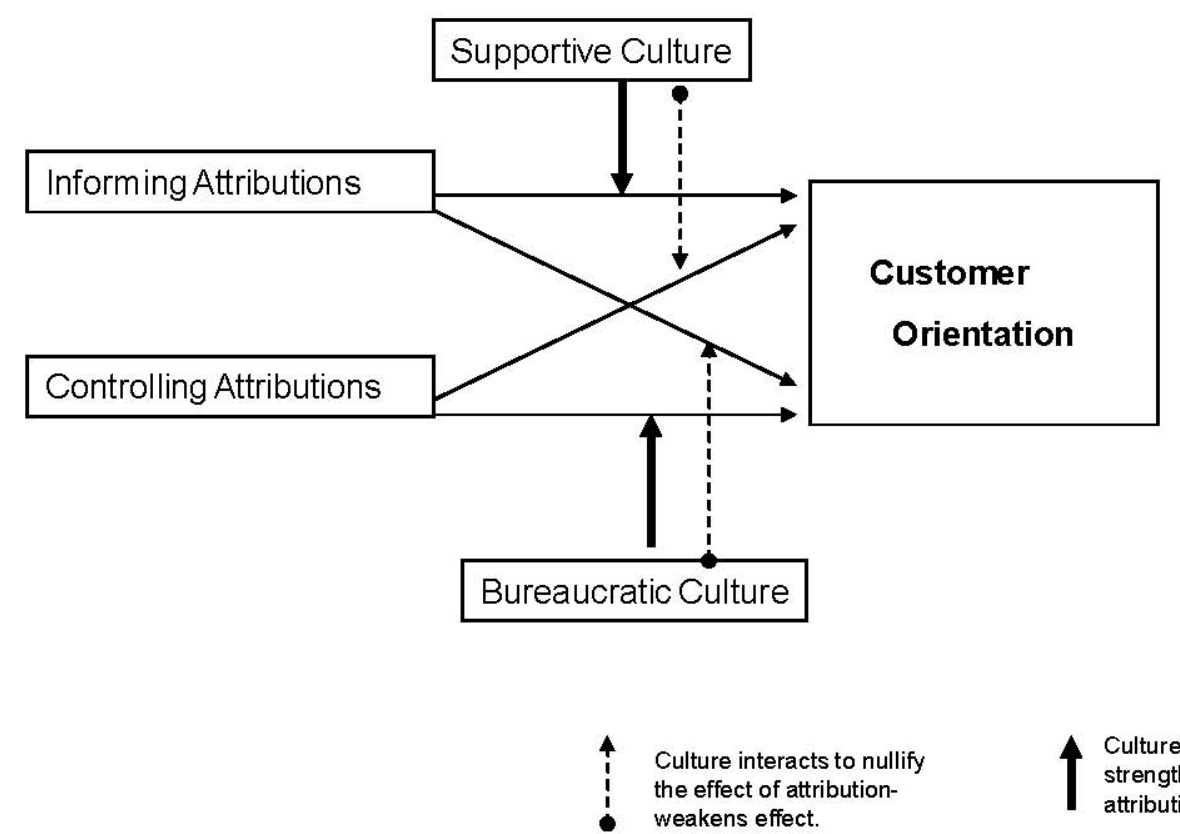

Culture interacts to strengthen the effect of attribution-amplifies effect.

$\mathrm{H}_{1}$ : Informing Attributions $(+) \rightarrow$ Customer Orientation

$\mathrm{H}_{2}$ : Controlling Attributions $(-) \rightarrow$ Customer Orientation

$\mathrm{H}_{3}$ : Supportive culture strengthens Informing Attributions $(+) \rightarrow$ Customer Orientation

$\mathrm{H}_{4}$ : Supportive culture weakens Controlling Attributions $(-) \rightarrow$ Customer Orientation

$\mathrm{H}_{5}$ : Bureaucratic culture strengthens Controlling Attributions $(-) \rightarrow$ Customer Orientation

$\mathrm{H}_{6}$ : Bureaucratic culture weakens Informing Attributions $(+) \rightarrow$ Customer Orientation 
Figure 2

Moderating Effect of Culture
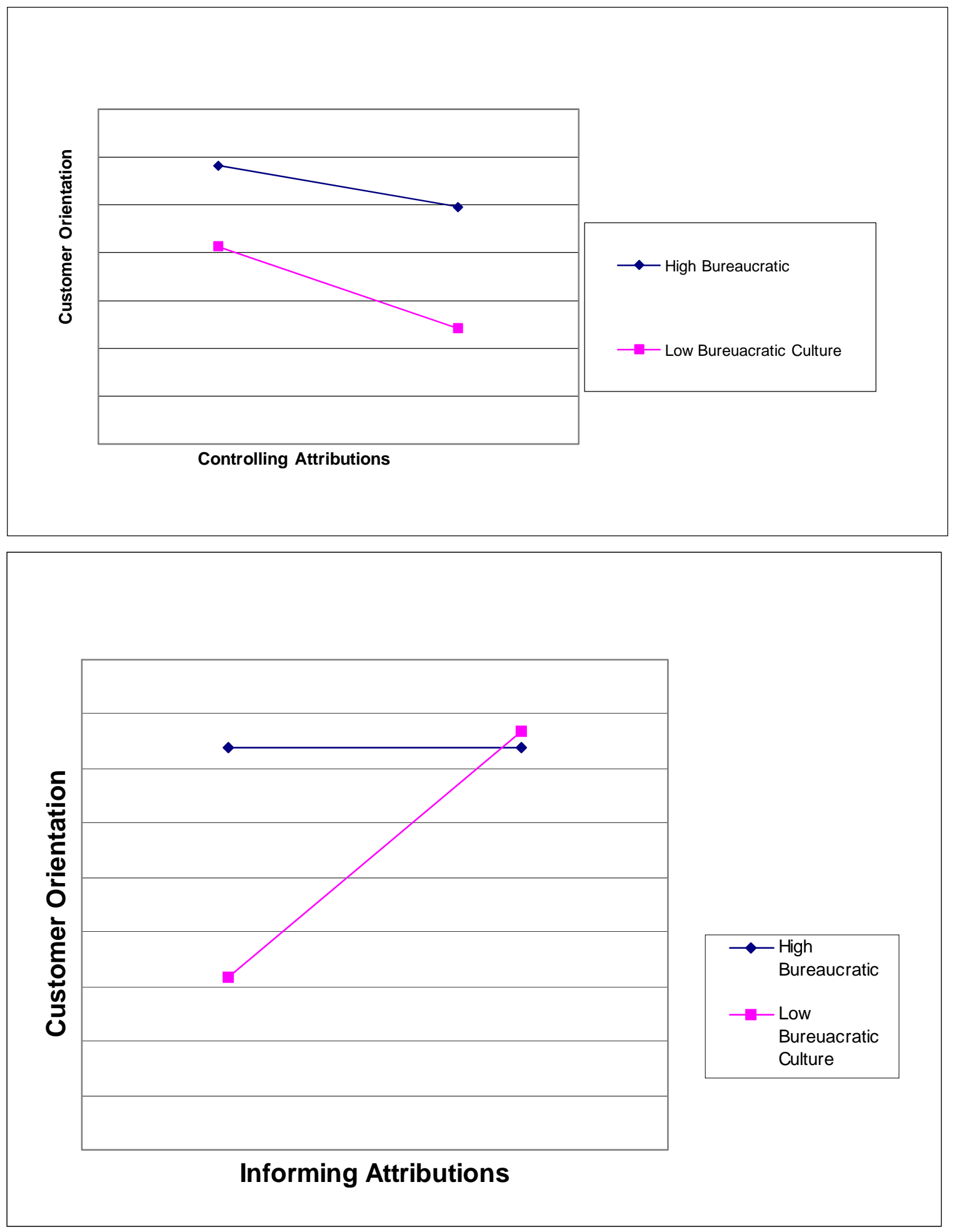


\section{References}

Adler, P.S. and Borys, B. (1996), "Two types of bureaucracy: Enabling and coercive," Administrative Science Quarterly, Vol. 41 No. 1, pp. 61-89.

Ahearne, M., Jones, E., Rapp, A., and Mathieu, J. (2008), "High touch through high tech: The impact of salesperson technology usage on sales performance via mediating mechanisms," Management Science, Vol. 54 No. 4, pp. 671-85.

Ahearne, M., Srinivasan, N. and Weinstein, L. (2004), "Effect of technology on sales performance: Progressing from technology acceptance to technology usage and consequence," Journal of Personal Selling \& Sales Management, Vol. 24 No. 4, pp. 297310.

Aiello, J.R. (1993), "Computer-based work monitoring: Electronic surveillance and its effects," Journal of Applied Social Psychology, Vol. 23 No. 7, pp. 499-507.

Akaah, I.P. (1993), "Organizational culture and ethical research behavior," Journal of the Academy of Marketing Science, Vol. 21 No. 1, pp. 59-63.

Alaniz, Richard D. (2010), "Watch Out: Monitoring Workers Has Benefits and Pitfalls," Snips, Vol. 79 No. 11, pp. 10, 12, 14.

Alder, G.S. and Ambrose, M.L. (2005), “An examination of the effect of computerized performance monitoring feedback on monitoring fairness, performance and satisfaction," Organizational Behavior and Human Decision Processes, Vol. 97 No. 2, pp. 161-77.

Ambrose, M.L. and Kulik, C.T. (1999), "Old friends, new faces: Motivation research in the 1990's," Journal of Management, Vol. 25 No. 3, pp. 231-92.

Anderson, J.C. and Gerbing, D.W. (1988), "Structural equation modeling in practice: A review and recommended two-step approach," Psychological Bulletin, Vol. 103 No. 3, pp. 411-23.

Baard, P. and Deci, E. and Ryan, R. (2001), "Intrinsic Need Satisfaction: A Motivational Basis of Performance and Well-Being in Two Work Settings," Journal of Applied Social Psychology, Vo. 34 No. 10, pp.2045-2068

Ball, K. (2010), “Workplace Surveillance: An Overview," Labor History, Vol. 51 No. 1, pp87106.

Bush, A.J., Bush, V.D., Orr, L.M., and Rocco, R.A. (2007), "Sales technology: Help or hindrance to ethical behaviors and productivity," Journal of Business Research, Vol. 60 No. 11, pp. 1198-1205.

Bush, V., Bush, A.J. and Orr,L. (2010), "Monitoring the Ethical Use of Sales Technology: An Exploratory Field Investigation," Journal of Business Ethics, Vol.95 No.2, pp. 239-257. 
Carroll, W. R. (2008), "The Effects of Electronic Performance Monitoring on Performance Outcomes: A Review and Meta-Analysis," Employee Rights and Employment Policy Journal, Vol. 12 No. 29, pp.

Challagalla, G., Shervani, T. and Huber, G. (2000), "Supervisory orientation and salesperson work outcomes: The moderating effect of salesperson location," Journal of Personal Selling \& Sales Management, Vol. 20 No. 3, pp. 161-71.

Deci, E.L. and Ryan, R.M. (1985), Intrinsic Motivation and Self-Determination in Human Behavior, Plenum Press, New York, NY.

Deci, E.L. and Ryan, R.M. (1987), "The support of autonomy and the control of behavior," Journal of Personality and Social Psychology, Vol. 53 No. 6, pp. 1024-37.

Deci, E.L., Connell, J.P. and Ryan, R.M. (1989), "Self-determination in a work organization," Journal of Applied Psychology, Vol. 74 No. 4, pp. 580-90.

Deci, E.L., Koestner, R. and Ryan, R.M. (2001), "Extrinsic rewards and intrinsic motivation in education: Reconsidered once again," Review of Educational Research, Vol. 71 No. 1, pp. 1-27.

Dew, R. (2009), "Creative resolve response: How Changes in Creative Motivation Relate to Cognitive Style,” Journal of Management Development, Vol. 28 No. 10, pp. 945-966.

Douthitt, E.A. and Aiello, J.R. (2001), "The role of participation and control in the effects of computer monitoring on fairness perceptions, task satisfaction and performance," Journal of Applied Psychology, Vol. 86 No. 5, pp. 867-74.

Druskat, V.U. and Wheeler, J.V. (2003), "Managing from the boundary: The effective leadership of self-managing work teams," Academy of Management Journal, Vol. 46 No. 4, pp. 43557.

Dunne, M. (2010) “Hype Cycle for CRM Sales, 2010” Gartner Research Report, July 28 ID:G00205008

Fornell, C. and Larcker, D.F. (1981), "Evaluating structural equation models with unobservable variables and measurement error," Journal of Marketing Research, Vol. 18 No. 1, pp. 3950 .

Franke, G.R. and Park, J. (2006), "Salesperson adaptive selling behavior and customer orientation: A meta-analysis," Journal of Marketing Research, Vol. 43 No. 4, pp. 693702.

Gagne, M. and Bhave, D. (2011), "Autonomy in the Workplace: An essential ingredient to employee engagement and well-being in every culture," Chirkov, V.I. (Ed), Ryan, R.M. (Ed) and Sheldon, K.M. (Ed), Human Autonomy In Cross-Cultural Context: 
Perspectives on the Psychology of Agency, Freedom and Well-Being, Springer Science + Business Media, New York, NY, pp.163-187

Gagne, M. and Deci, E.L. (2005), "Self-Determination Theory and Work Motivation, “ Journal of Organizational Behavior, Vo.26 No. 3, pp. 331-362.

Gagne, M., Koestner,R. and Zuckerman, M. (2000), "Facilitating acceptance of Organizational Change: The Importance of Self-Determination," Journal of Applied Social Psychology, Vol. 30 No. 9, pp. 1843-1852.

Gohmann, S.F., Guan, J., Barker, R.M., and Faulds, D.J. (2005), "Perceptions of sales force automation: Differences between sales force and management," Industrial Marketing Management, Vol. 34 No. 4, pp. 337-43.

Greguras, G. J. and Diefendorff, J.M. (2009), "Different Fits Satisfy Different Needs: Linking Person-Environment Fit to Employee Commitment and Performance Using SelfDetermination Theory," Journal of Applied Psychology, Vol. 94 No.2, pp. 465-477.

Haggar, M.S. and Chatzisarantis, N.L. (2009), "Integrating the Theory of Planned Behaviour and Self-Determination Theory In Health Behaviour: A Meta-Analysis," British Journal of Health Psychology, Vol. 14 No 2, pp. 275-302.

Harris, E.G., Mowen, J.C. and Brown, T.J. (2005), "Re-examining salesperson goal orientations: Personality influencers, customer orientation, and work satisfaction," Academy of Marketing Science Journal, Vol. 33 No. 1, pp. 19-35.

Harris, L.C. and Ogbonna, E. (2006), "Service sabotage: A study of antecedents and consequences," Academy of Marketing Science Journal, Vol. 34 No. 4, pp. 543-58.

Homburg, C., Muller, M. and Klarmann, M. (2011), "When Should the Customer Really Be King? On the Optimum Level of Salesperson Customer Orientation in Sales Encounters," Journal of Marketing, Vol. 75 No. 1, pp. 55-74.

Hu, L. and Bentler, P.M. (1999), "Cutoff criteria for fit indexes in covariance structure analysis: Conventional criteria versus new alternatives," Structural Equation Modeling, Vol. 6 No. 1, pp. 1-55.

Hunter, G.K. and Perreault, W.D. (2006), "Sales technology orientation, information effectiveness and sales performance," Journal of Personal Selling \& Sales Management, Vol. 26 No. 2, pp. 155-70.

Hunter, G.K. and Perreault, W.D. (2007), "Making sales technology effective," Journal of Marketing, Vol. 71 No. 1, pp. 16-34. 
Iivari, J. and Huisman, M. (2007), "The relationship between organizational culture and the deployment of systems development methodologies," MIS Quarterly, Vol. 31 No. 1, pp. $35-58$.

Jayachandran, S., Sharma, S., Kaufman, P. and Raman, P. (2005), “The Role of Relational Information Processes and Technology Use in Customer Relationship Management," Journal of Marketing, Vol. 69 No. 2, pp. 177-192.

Johnson, D.S. and Bharadwaj, S. (2005), "Digitization of selling activity and sales force performance: An empirical investigation," Journal of the Academy of Marketing Science, Vol. 33 No. 1, pp. 3-18.

Joshi, A. W. and Randall, S. (2001), "The Indirect Effects of Organizational Controls on Salesperson Performance and Customer Retention," Journal of Business Research, Vol. 54 No. 1, pp. 1-9.

Kelley, S.W., Hoffman, K.D. and Davis, M.A. (1993), “A typology of retail failures and recoveries," Journal of Retailing, Vol. 69 No. 4, pp. 429-37.

Kidwell, R.E. and Bennett, N. (1994), "Employee reactions to electronic control systems," Group \& Organization Studies, Vol. 19 No. 2, pp. 203-18.

Kim, H. and Yukl, G. (1998), "Relationships of managerial effectiveness and advancement to self-reported and subordinate-reported leadership behaviors from the multiple linkage model," in Dansereau, F. and Yammarino, F.J. (Eds.), Leadership: The Multiple-Level Approaches Classical and New Wave, JAI Press, Inc., London, pp. 243-64.

Lindell, M.K. and Whitney, D.J. (2001), “Accounting for common method variance in crosssectional research designs,” Journal of Applied Psychology, Vol. 86 No. 1, pp. 114-21.

Liu, D., Chen, X. and Yal, X. (2011), "From Autonomy to Creativity: A Multilevel Investigation of the Mediating Role of Harmonious Passion," Journal of Applied Psychology, Vol. 96 No 2, pp. 294-309.

Mathieu, J., Taylor, S.R. and Ahearne, M. (2007), "A longitudinal cross-level model of leader and salesperson influences on sales force technology use and performance," Journal of Applied Psychology, Vol. 92 No. 2, pp. 528-37.

Matsuo, M. (2009), "The Influence of Sales Management Control on Innovativeness of Sales Departments," Journal of Personal Selling and Sales Management, Vol.29 No.4, pp.321331.

Morhart, F., Herzog, W. and Tomczak, T, (2009), "Brand-Specific Leadership: Turning Employees into Brand Champions," Journal of Marketing, Vol. 73 No. 3, pp. 122-142. 
Moutot, J.M. and Bascoul, G. (2008), "Effects of sales force automation use on sales force activities and customer relationship management processes," Journal of Personal Selling \& Sales Management, Vol. 28 No. 2, pp. 167-84.

Nord, G.D., McCubbins, T.F. and Nord, J.H. (2006), "E-monitoring in the workplace: Privacy, legislation, and surveillance software," Communications of the ACM, Vol. 49 No. 8, pp. 73-77.

Oliver, R.L. and Anderson, E. (1994), “An empirical test of the consequences of behavior- and outcome-based sales control systems,” Journal of Marketing, Vol. 58 No. 4, pp. 53-67.

Onyemah, V., Rouzies, D., Panagopoulos, N.G. (2010), "How HRM Control Affects BoundarySpanning Employees' Behavioural Strategies and Satisfaction: The Moderating Impact of Cultural Performance Orientation," The International Journal of Human Resource Management, Vol. 21 No. 11, pp. 1951-1975.

Periatt, J.A., LeMay, S.A. and Chakrabarty, S. (2004), "The selling orientation-customer orientation (SOCO) scale: Cross-validation of the revised version," Journal of Personal Selling \& Sales Management, Vol. 24 No. 1, pp. 49-54.

Perrone, V., Zaheer, A. and McEvily, B. (2003), "Free to be trusted? Organizational constraints on trust in boundary spanners," Organization Science, Vol. 14 No. 4, pp. 422-39.

Phillips, J. S. and Lord, R.G. (1980), "Determinants of Intrinsic Motivation: Locus of Control and Competence Information as Components of Deci's Cognitive Evaluation Theory," Journal of Applied Psychology, Vol. 65 No. 2, pp. 211-218.

Pittman, T.S., Davey, M.E., Alafat, K.A., Wetherill, K.V. and Kramer, N.A. (1980), "Informational Versus Controlling Verbal Rewards," Personality and Social Psychology Bulletin, Vol. 6 No 2., pp. 228-233.

Pullig, C., Maxham, J.G., III and Hair, J.F. (2002), "Salesforce automation systems: An exploratory examination of organizational factors associated with effective implementation and salesforce productivity," Journal of Business Research, Vol. 55 No. 5, pp. 401-15.

Roman, S. and Icobucci, D. (2010), “Antecedents and Consequences of Adaptive Selling Confidence and Behavior: A Dyadic Analysis of Salespeople and Their Customers," Journal of the Academy of Marketing Science, Vol.38 No. 2, pp. 363-382.

Ryan, R.M. (1982), "Control and Information in the Intrapersonal Sphere: An Extension of Cognitive Evaluation Theory," Journal of Personality and Social Psychology, Vol. 43 No. 3, pp. 450-461.

Saxe, R. and Weitz, B.A. (1982), "The SOCO scale: A measure of the customer orientation of salespeople," Journal of Marketing Research, Vol. 19 No. 3, pp. 343-51. 
Schillewaert, N., Ahearne, M.J., Frambach, R.T., and Moenaert, R.K. (2005), “The adoption of information technology in the sales force," Industrial Marketing Management, Vol. 34 No. 4, pp. 323-36.

Shalley, C.E. and Perry-Smith, J.E. (2001), "Effects of social-psychological factors on creative performance: The role of informational and controlling expected evaluation and modeling experience," Organizational Behavior and Human Decision Processes, Vol. 84 No. 1, pp. 1-22.

Sharma, A. (2007), "The shift in sales organizations in business-to-business services markets," Journal of Services Marketing, Vol. 21 No. 5, pp. 326-33.

Sharma, S., Durand, R.M. and Gur-Arie, O. (1981), "Identification and analysis of moderator variables," Journal of Marketing Research, Vol. 18 No. 3, pp. 291-300.

Speier, C. and Venkatesh, V. (2002), "The hidden minefields in the adoption of sales force automation technologies," Journal of Marketing, Vol. 66 No. 3, pp. 98-111.

Stanton, J.M. and Weiss, E.M. (2000), "Electronic monitoring in their own words: An exploratory study of employees' experiences with new types of surveillance," Computers in Human Behavior, Vol. 16 No. 3, pp. 423-40.

Stock, R. M. and Hoyer, W.D. (2005), “An Attitude-Behavior Model of Salespeople's Customer Orientation," Journal of the Academy of Marketing Science, Vol. 33 No. 4, pp.536-552.

Stone, D. N., Deci, E.L. and Ryan, R.M. (2009), "Beyond Talk: Creating Autonomous Motivation Through Self-Determination Theory," Journal of General Management, Vol. 34 No. 3, pp.75-88.

Sundaram, S., Schwarz, A., Jones, E., and Chin, W.W. (2007), "Technology use on the front line: How information technology enhances individual performance," Journal of the Academy of Marketing Science, Vol. 35 No. 1, pp. 101-12.

The Economist (2009) "Big Brother Bosses: Employers Spying on Staff," Vol. 392 No.8648, pp. 71-72.

Thomas, R.W., Souter, G.N. and Ryan, M.M. (2001), “The selling orientation-customer orientation (S.O.C.O.) scale: A proposed short form," Journal of Personal Selling \& Sales Management, Vol. 21 No. 1, pp. 63-69.

Tynan, D. (2006), “Brave New Sales World,” Sales \& Marketing Management, Vol. 158 No.3, pp. 34-38. 
van Vuuren, M., Veldkamp, B.P., deJong, M.D.T., and Seydel, E.R. (2008), "Why work? Aligning foci and dimensions of commitment along the axes of the competing values framework," Personnel Review, Vol. 37 No. 1, pp. 47-65.

Vansteenkite, M., Niemec, C.P., and Soenens, B. (2010), "The Development of the Five MiniTheories of Self-Determination Theory: An Historical Overview, Emerging Trends and Future Directions," Advances in Motivation and Achievement, Vol. 16A, pp. 105-165.

Verbeke, W., Dietz, B. and Verwaal, E. (2011), "Drivers of Sales Performance: A Contemporary Meta-Analysis. Have salespeople become knowledge brokers?," Journal of the Academy of Marketing Science, Vol.39 No. 4, pp. 407-428.

Wallach, E.J. (1983), "Individuals and organizations: The cultural match," Training and Development Journal, Vol. 37 No. 2, pp. 29-36

Weinreb, M. (2002), "Remote Control," Sales \& Marketing Management, Vol. 154 No.10, pp. 24.

Zweig, D. and Webster, J. (2002), "Where is the line between benign and invasive? An examination of psychological barriers to the acceptance of awareness monitoring systems," Journal of Organizational Behavior, Vol. 23 No. 5, pp. 605-33. 